\title{
The Impact of Household Waste on Slum Neighborhoods
}

\author{
Natsir Abduh $\mathbf{M}^{1, *}$, Rumpang Yusuf ${ }^{2}$ and Fikruddin Buraerah ${ }^{3}$ \\ ${ }^{1}$ Associate Professor, Department of Civil Engineering, Faculty of Engineering, Universitas Bosowa. \\ ${ }^{2}$ Department of Civil Engineering, Faculty of Engineering, Universitas Bosowa, Makassar, 90231 Indonesia. \\ ${ }^{3}$ Department of Environmental Engineering, Faculty of Engineering, Universitas Bosowa, Makassar, 90231 Indonesia.
}

\begin{abstract}
One of the reasons for environmental quality degradation is the behavior of the community in treating household waste. Contamination of rubbish to the environment contributes to contaminating groundwater for household consumption, which results in disease. This type of descriptive quantitative research analyzes the impact of improper waste disposal and the effect of providing waste management interventions and training on changes in household waste management practices. The study was conducted in North Sinjai-Regency, South Sulawesi Province, Indonesia, with 40 respondents who are people who live in the Lappa area. The research used a quasi-experimental design with one group pre-and post-test system. The results showed an impact due to the improper disposal of waste on diarrhea disease $10 \%$, dengue fever $15 \%$. The provision of interventions and training has effectively promoted changes in practices in household waste management.
\end{abstract}

Keywords: Household Waste, Slum-Area

\section{INTRODUCTION}

Household waste is generated from activities at home, can be liquid, reliable, and a lot of it from kitchens, bathrooms, laundry, and human waste (feces). The result of this activity is trash, or something that is not used can be classified as Hazardous and Toxic Material (B3) waste with a higher waste content than industrial waste so that its nature can pollute and damage the environment and endanger human health [1], [2]. Every household produces waste, which, if not handled properly, will harm environmental conditions. Besides being dangerous to the environment, it also disturbs human health because in the waste content some germs and bacteria cause various diseases [3]. Household waste, both in the form of liquid and solid, can pollute the soil, damage the water ecosystem, affect the community's drinking water sources, source disease seeds, and cause unpleasant odors [4]. Environmental pollution that occurs in water areas will cause aquatic biota such as fish to die from poisoning; Besides that, the problem of environmental pollution that comes from waste can also decrease water quality and disease transmission [5]. In connection with this, waste treatment requires particular and

\footnotetext{
* First Author \& Correspondence Author: Natsir Abduh M.

E-mail ID: mnatsirabduh@gmail.com
}

optimally planned handling before being discharged or discharged into sewers [1], [3].

Household waste is classified into two types, namely organic waste containing carbon elements derived from living things such as human and animal waste, food scraps, and dry leaves [5], [6]. Organic waste is classified as waste with characteristics that it is easier to decompose and decompose by microorganisms. Besides, there is also inorganic waste, which has no carbon element, such as plastics, rubber, batteries, and cans [3],[6]. Inorganic waste requires time and a long process to decompose, such as waste from used cans containing rusty sediments that can damage soil structure and pollute water. Seeing the significant impact of household waste on the environment, it is necessary to manage household waste properly. Therefore, every family has an essential role in managing the household waste it produces [6],[7]. As one of the fourth most populous countries globally, Indonesia generates around 850 tons of household waste every day. The problem that occurs is a problem that has been going on for a long time, so that awareness and the government's role, private sector, and society are needed to discuss waste in their environment. [6]. Various kinds of efforts and government strategic steps in household waste management, namely collecting, transporting, processing, and recycling. However, this method requires adequate and even modern facilities or equipment, such as transporting machines or waste recycling machines. A simple way to minimize household waste is to reduce usage (reduce), which creates waste and reuse (reuse) materials that are still commonly used [8], [9], [10].

The problem of household waste is closely related to conditions that are often found in slum settlements. Slum settlements themselves are a deterioration in the physical environment characterized by poor housing conditions such as inadequate housing, buildings close together without a house yard, dense population, and insufficient environmental facilities [11], [12]. This study objectively describes the slum settlements in the Lappa Area of North Sinjai Regency, Indonesia. The problem of waste is one of the various health problems that need to be prioritized. The availability of disposal facilities in the form of garbage bins and septic tanks that comply with standards is not easy. In the Lappa area, South Sulawesi, septic tanks need special attention because they are not up to standard septic tanks are the beginning of disease problems in the area, such as 
diarrhea, typhoid, dysentery, intestinal worms, and itching. Besides, non-standard septic tanks can contaminate water sources and reduce environmental aesthetics. The Lappa area, North Sinjai District, Sinjai Regency, is one of the residential areas in South Sulawesi Province. This area's environment is a slum environment that is not suitable for habitation because the sanitation and drainage systems in this area do not meet the quality or complexity requirements (See. Figure 1). The condition of the residential area in the Lappa area, which is located on the edge of a river that is often flooded, makes people not motivated to protect the environment. To anticipate the worsening of environmental conditions, the Sinjai Regency Government issued a regional regulation on the prevention and improvement of the quality of Housing and Slum Settlements, a Regional Regulation which in principle has guidelines and specifications for domestic waste treatment through an approach to improving the quality of housing infrastructure and residential areas. The problem of household waste, especially in the object of study, is closely related to the culture of the people accustomed to littering and household waste carelessly. Public awareness is needed to overcome all environmental problems. One of the causes of ecological quality degradation is household consumption behavior requiring intervention and guidance from various parties in changing behavior that has become a culture.

\section{RESEARCH METHOD}

This type of research uses a descriptive quantitative approach to analyze the impact of inappropriate household waste disposal on the study object area and the effect of providing waste management interventions and training on changes in household waste management practices in the area. The research was conducted in March 2018 in the North Sinjai Regency, South Sulawesi Province, with a sample of 40 respondents who were people living in the Lappa area. The data analysis tool used a quasi-experimental design with one group pre-and post-test system. The research location is $162.3 \mathrm{~km}$, which can be reached by 4 -wheeled vehicles for approximately 4 hours and shown in Figure 1.

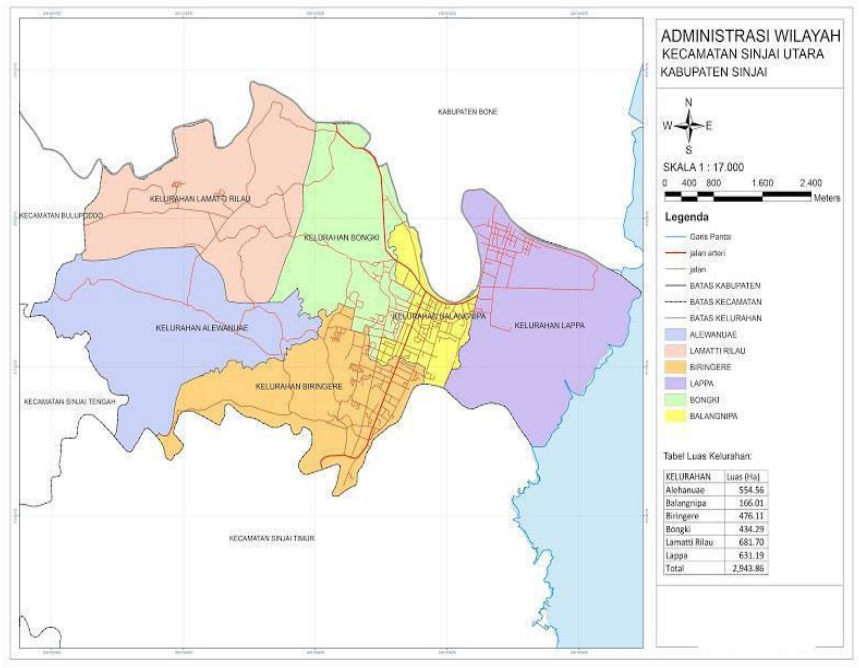

Figure 1. Map of Study Objects Location
The construction of community houses in the dominant research location is made of wood with zinc roofs, and the building structure uses central wooden poles in the form of stilt houses. The house's shape is deliberately made high or with a house on stilts to avoid flooding when the river overflows. The distance between one place and another is classified as tight so that sunlight and air circulation are minimal. The building landscape is also not well ordered, so that this condition causes the appearance of the research area to look slum. Requirements for constructing buildings according to government regulations regarding the distance from the road line are not obeyed. In building houses, people have not followed government regulations, such as building permits. The condition of the community houses can be seen in Figure 2. The distance between the places is very close and from the road so that the land for making septic tanks is minimal. Limited land on the home page causes the distance between clean water sources and septic tanks to be close together.

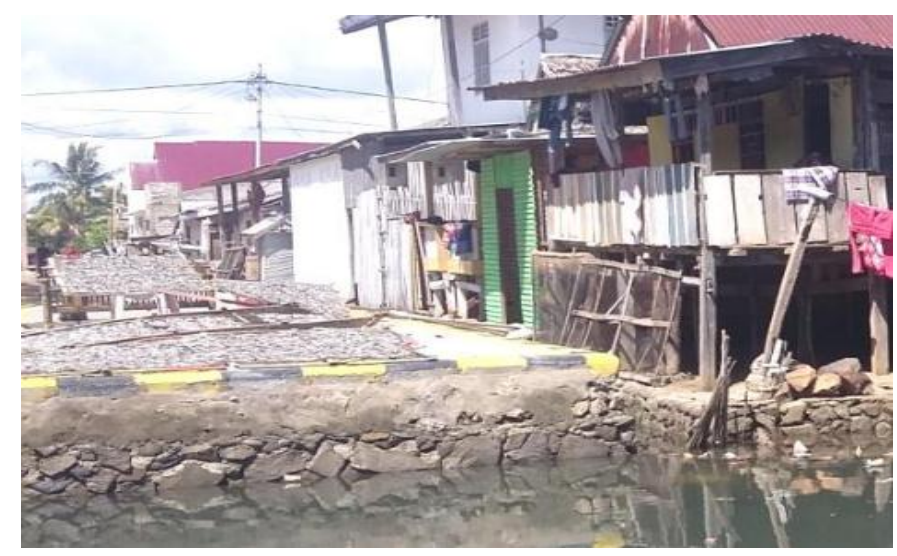

Figure 2. Building and Settlement Conditions for Study Objects

Roads have an essential role in supporting activities in the Lappa Area. The road network functions as a public transportation route such as; trade, socio-culture, and religion. The residents' activities using the road network are accustomed to unfavorable conditions consisting of rocky soil with minimal asphalt. Besides the function of the road, children use it as a play area and trade. The road conditions in the Lappa Area are illustrated in Figure 3. Where the high water level mostly causes the damage to roads, even the water rises to the road surface, which causes the road body to become damaged due to being submerged in overflowing river water. The dimensions of narrow roads, stagnant water in the road body, and roads with holes also cause inconvenience to be used.

The field survey results show that the road facilities are based on several criteria such as 1). The road section consists of secondary arterial roads, neighborhood roads, and footpaths, 2). The road damage level, namely, four roads that are in damaged condition and two roads that are in good condition, 3 ). Some roads have an average width of 4 meters on the shoulder of the road. Apart from the conditions of settlements, buildings, and roads, there are also drainage conditions. The drainage network in the Lappa Area is mostly damaged; the situation is not 
International Journal of Engineering Research and Technology. ISSN 0974-3154, Volume 13, Number 9 (2020), pp. 2374-2379

(C) International Research Publication House. https://dx.doi.org/10.37624/IJERT/13.9.2020.2374-2379

functioning; there are even some roads that do not have water channels. The drainage conditions are shown in Figure 4.

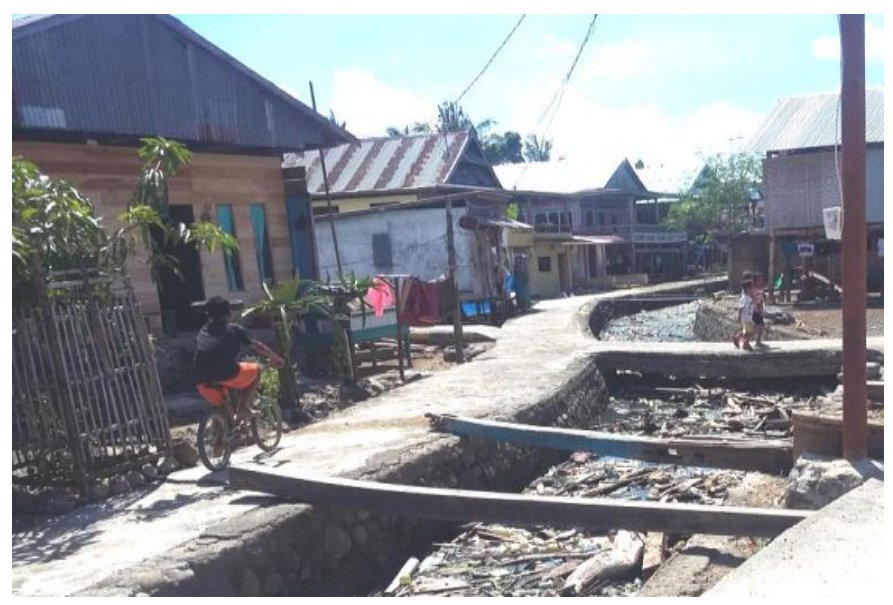

Figure 3. Road Condition of the Study Object

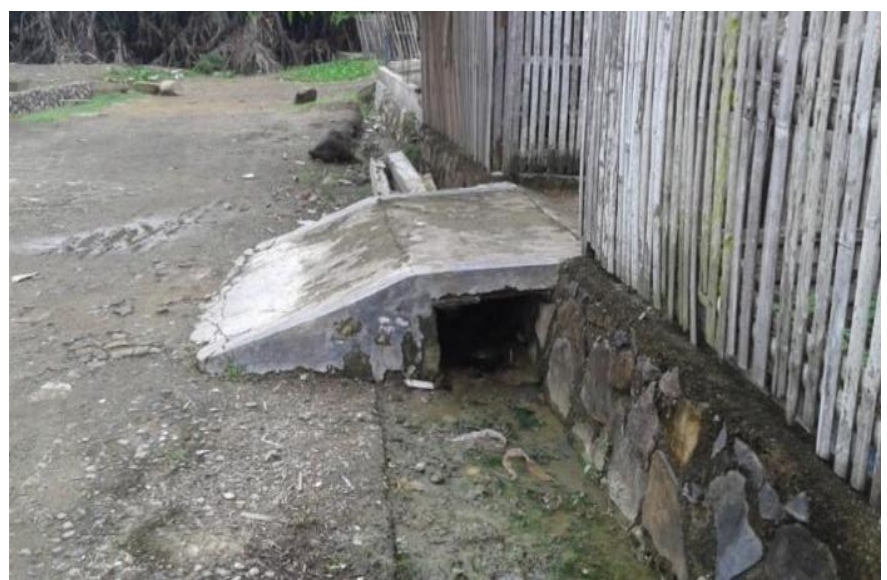

Figure 4. Drainage Conditions of Study Objects

Figure 4 illustrates the drainage construction condition made by digging the soil and not using concrete as the base for the sub-surface drainage. Regarding the shape of the object of study, we also describe the condition of the water below. Water is one of the essential needs for the survival of humans and other living things; as a limitation, clean water is water that meets the requirements for a drinking water supply system. The purpose of the clean water supply system is to distribute/supply clean water to consumers in sufficient quantities, especially in the Lappa area. Difficult water sources due to river flow inundating the Lappa area and frequent flooding caused by overflowing rivers have spurred the community to make deep bore wells. Apart from that, another supply of drinking water also comes from the government, the community's primary daily water source. MCK (shower-wash-toilet) is the immediate daily need for all humans. The organization generally uses rivers to facilitate these needs. Food waste and feces are discharged directly into the river. The habit of disposing of garbage now into the river or around the house is possible because the environment is very supportive, as shown in Figure 5.

Floods and high water inundation of houses will make it more challenging to make septic tanks for community needs. Besides, the condition of environmental sanitation in a settlement can be seen from the ownership of a family or public toilet that meets the technical requirements. The low level of public awareness of environmental and health care has made them dispose of feces directly into the river. Areas that frequently flood during the rainy season have an impact on the use of septic tanks not functioning. This is shown in Figure 6.

The construction of the septic tank is watertight to avoid contaminating the surrounding environment from fecal waste. The ideal septic tank building distance from a water source is at least 10 meters. The Septic tank is located in such a way as to allow the smooth flow of wastewater from the building to the catchment area and is also equipped with an absorption tank.

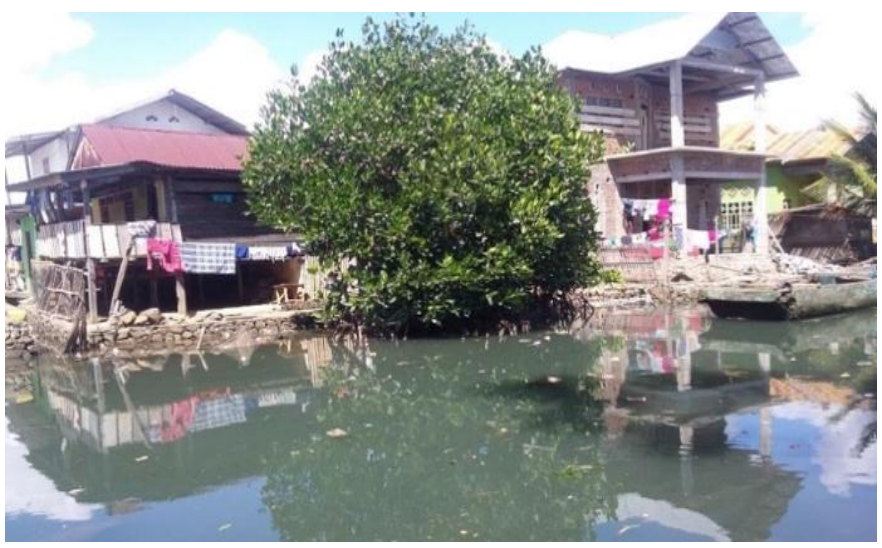

Figure 5. Housing Areas in Watershed

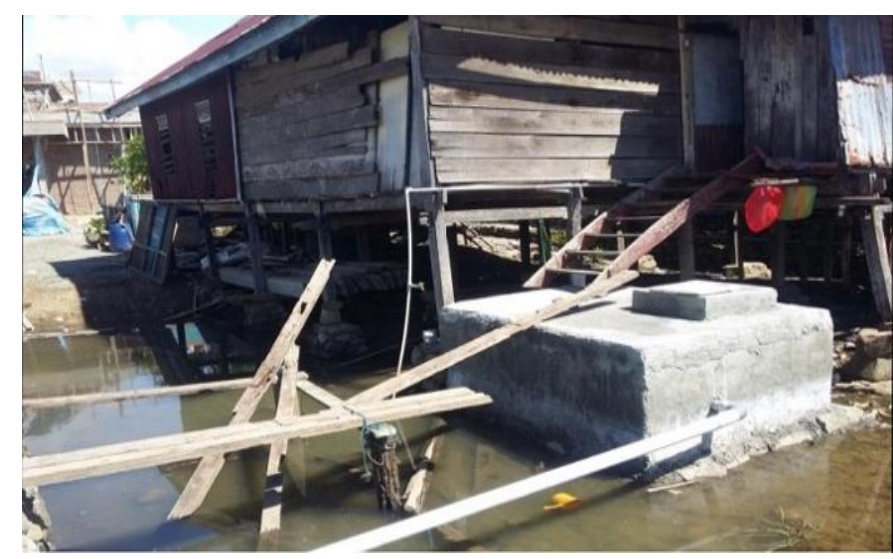

Figure 5. Septic Tank Construction of Study Object

\section{RESULT AND DISCUSSION}

\subsection{Results of Data}

The results of the analysis of water needs in the Lappa area based on water sources for the community can be seen in Table 1 . Besides, the source and availability of clean water, 
International Journal of Engineering Research and Technology. ISSN 0974-3154, Volume 13, Number 9 (2020), pp. 2374-2379

(C) International Research Publication House. https://dx.doi.org/10.37624/IJERT/13.9.2020.2374-2379

namely $90 \%$, comes from deep wells, and $10 \%$ comes from local governments' water tanks.

Table 1. Daily sources of clean water in the Research Area

\begin{tabular}{|c|c|c|c|}
\hline No & Source of Clean Water & Amount & $\%$ \\
\hline 1 & Boreholes & 36 & 90 \\
\hline 2 & $\begin{array}{l}\text { Local Government Water } \\
\text { Tanks }\end{array}$ & 4 & 10 \\
\hline \multicolumn{2}{|c|}{ Total } & 40 & 100 \\
\hline
\end{tabular}

Based on table 1, it can be explained that the respondents' need for clean water generally uses drilled wells; in this case, it can be seen from most of the residents of the Lappa area that there are private wells in the yard of their house with the highest percentage of $90 \%$. In comparison, residents who use government water tanks get the rate $10 \%$, and other clean water uses for the Lappa Area residents only use the river as a container for clean water needs. Therefore, household waste and feces that are disposed of into the environment have an impact on groundwater. The Lappa Area people do this by disposing of debris into the drainage in their residential area. This community habit creates vectors, such as flies and mosquitoes, and strong odors. As a result of this waste, groundwater quality is reduced and is not suitable for consumption. Based on the results of the analysis of the people's habits in the Lappa area to dispose of household waste in two ways, as shown in Table 2.

Table 2. Results of the Analysis of Waste Disposal Habits

\begin{tabular}{|c|l|c|c|}
\hline No. & \multicolumn{1}{|c|}{ Sewer } & $\begin{array}{c}\text { Frequency } \\
\text { (f) }\end{array}$ & $(\%)$ \\
\hline 1 & Septic tank & 26 & 65 \\
\hline 2 & Drainage & 14 & 35 \\
\hline \multicolumn{2}{|c|}{ Total } & 40 & 100 \\
\hline
\end{tabular}

Based on Table 2, it can be explained that the level of disruption of the process in the disposal of dirty water or feces in the Lappa area is that there are 26 households with a percentage of $65 \%$ and some respondents complained about the existence of fecal waste that is disposed of directly into rivers and drains. Dirty with a $35 \%$ rate, due to an unpleasant smell or aroma and unpleasant sight in their eyes that were dumped illegally by some Lappa area; this can be seen in Figure 3, where the people of Lappa Village still throw dirty water and wastewater. Feces directly on the drainage or river around it. Waste contaminated with the environment affects the quality of life necessities, primarily; odor, air, and water for consumption. Its management needs attention to minimize the impact on disease. The results of the analysis of the effects caused by the habit of disposing of waste against several diseases are shown in Table 3.
Table 3. Results of the Analysis of the Diseases Caused

\begin{tabular}{|c|l|c|c|}
\hline No. & \multicolumn{1}{|c|}{ Types of diseases } & $\begin{array}{c}\text { Frequency } \\
\text { (f) }\end{array}$ & $(\%)$ \\
\hline 1 & Diarrhea & 4 & 10 \\
\hline 2 & Dengue fever & 6 & 15 \\
\hline 3. & Itchy & 34 & 75 \\
\hline \multicolumn{2}{|c|}{ Total } & 40 & 100 \\
\hline
\end{tabular}

As a result of improper disposal of waste, Based on table 3, it can be explained that $15 \%$ of respondents stated that they had experienced a disease due to a pile of garbage in the drain, the types of illnesses that had been experienced by respondents included dengue fever, and $10 \%$ of respondents stated that they had experienced diarrhea and were dominant Is hives. Although there are still residents who have never felt the disease, they are still cautious about the conditions that have spread and are thought by some residents. Generally, the diseases they cause are quickly spread through mosquito bites or by the onset of infectious diseases. Therefore it needs awareness from every resident of the Lappa area always to maintain cleanliness.

The Role of Community in Household Waste Management is crucial where the socio-cultural aspects and community characteristics play an important role in waste management. The analysis results of the form of community participation in the power of household waste in the Lappa area are shown in Table 4.

Table 4. Community role in household waste management (in Person)

\begin{tabular}{|l|l|c|c|c|c|}
\hline No & $\begin{array}{l}\text { Community } \\
\text { Role }\end{array}$ & Active & $\begin{array}{c}\text { Not } \\
\text { active }\end{array}$ & Total & Contribution \\
\hline 1 & $\begin{array}{l}\text { Cleaning } \\
\text { the house }\end{array}$ & 12 & 28 & 40 & 30 \\
\hline 2 & $\begin{array}{l}\text { Clean the } \\
\text { drainage }\end{array}$ & 25 & 15 & 40 & 62.5 \\
\hline 3 & $\begin{array}{l}\text { Make a } \\
\text { septic tank }\end{array}$ & 26 & 14 & 40 & 65 \\
\hline \multicolumn{2}{|c|}{ Mean } & 21 & 19 & 40 & 52.5 \\
\hline
\end{tabular}

Table 4 shown that through 40 respondents, it can be seen that the role of the community in managing dirty water waste in the Lappa area is $52.5 \%$. This means that residents' level of awareness in managing contaminated water waste in house cleanliness, cooperation in cleaning waterways, and making individual septic tanks and communal septic tanks is lacking. The government's role in managing household waste in the Lappa Area is the Accelerated Residential Sanitation Development Program (PPSP). The sanitation program in Sinjai District, concerning Program Priorities and Activities for Settlement Wastewater, is organized into several activities. 
International Journal of Engineering Research and Technology. ISSN 0974-3154, Volume 13, Number 9 (2020), pp. 2374-2379

(C) International Research Publication House. https://dx.doi.org/10.37624/IJERT/13.9.2020.2374-2379

\subsection{Discussion}

The condition of the slum area's location can be described by assessing its level of the slum. State of necessary facilities and infrastructure to meet public facilities' needs in slum areas, namely clean water services, and environmental sanitation conditions. Conditions of solid waste and rainwater drains, road conditions, the size of green open spaces-socio-economic conditions to determine the level of welfare in the slum area. The various problems arising from the existence of these slum settlements provide evidence that slum settlements will also impact the quality of the environment in the surrounding community. Garbage can be interpreted as objects that are not needed and should be thrown away because waste is one of the slum environment causes. There are still many people who think garbage is a trivial thing. Garbage is a tremendous negative impact if it is left alone. In this case, it can be concluded that the community has not realized how big the impact of slum on the environment is due to waste. In our life, of course, the slum environment will affect our health. In a sense, the local people do not care about the environment. Slum settlements are unfit for habitation because they do not meet the housing requirements, both technically and non-technically. A slum settlement can be associated with poverty. In general, it is in slum settlements where most of the less fortunate people live, and their messy houses are often found in urban areas. Slum settlements also logically must have poor infrastructure and supporting facilities for accommodations.

Sustainable sanitation is sanitation that focuses on ecological aspects [13], [14]. The approach is based on the principle of pollution prevention. Treating human waste and utilizing urine and feces as agricultural resources. Environmental sanitation is designed to solve several problems from conventional sanitation systems such as septic tanks, sewerage systems, and landfills. [14], [15], [1]. Environmental sanitation is based on the idea that urine and feces are resources in the food chain. This system aims to save water, protect water resources, prevent pollution, and improve the community's economic conditions.

Sustainable waste management is a system in which there is; 1 . Ecology is a reciprocal relationship between living things and their environment. Solid waste management must ensure the sustainability of the ecosystem and the carrying capacity of the domain. 2. Socio-culture means that the community must be involved in planning, implementing, and supervising solid waste management. 3. Economy, many economic benefits can be obtained from the results of waste management. To get these benefits, solid waste management must guarantee economic benefits for the community.

\section{CONCLUSION}

The relationship between humans and the environment is very close; where there is an increase in human needs, there will be a decrease in the quality of the environment and vice versa. Likewise, the problem of population density, which is increasingly booming, causes a high number of slum settlements in urban areas. Besides, slum settlements whose construction is without careful planning make the environmental impact even more complicated.

Many parties will be affected by slum settlements that do not take the side of environmental sustainability. This is due to the lack of supporting facilities and infrastructure so that people use other alternatives, which in the future will further damage the environment, such as dumping garbage into rivers. Therefore, development must pay attention to the environment balanced with the concept of sustainable development.

\section{REFERENCES}

[1] J. R. Núñez Collado and H.-H. Wang, "Slum upgrading and climate change adaptation and mitigation: Lessons from Latin America," Cities, vol. 104, p. 102791, 2020.

[2] A. Sarkar and R. Bardhan, "Socio-physical liveability through socio-spatiality in low-income resettlement archetypes - A case of slum rehabilitation housing in Mumbai, India," Cities, vol. 105, p. 102840, 2020.

[3] A. G. Ross, M. Rahman, M. Alam, K. Zaman, and F. Qadri, "Can we 'WaSH' infectious diseases out of slums?," Int. J. Infect. Dis., vol. 92, pp. 130-132, 2020.

[4] N. Uddin, "Assessing urban sustainability of slum settlements in Bangladesh: Evidence from Chittagong city," J. Urban Manag., vol. 7, no. 1, pp. 32-42, 2018.

[5] M. V. Michiani and J. Asano, "Physical upgrading plan for slum riverside settlement in traditional area: A case study in Kuin Utara, Banjarmasin, Indonesia," Front. Archit. Res., vol. 8, no. 3, pp. 378-395, 2019.

[6] F. C. Alam, E. Sembiring, B. S. Muntalif, and V. Suendo, "Microplastic distribution in surface water and sediment river around slum and industrial area (case study: Ciwalengke River, Majalaya district, Indonesia)," Chemosphere, vol. 224, pp. 637-645, 2019.

[7] M. N. Adnan, R. Safeer, and A. Rashid, "Consumption based approach of carbon footprint analysis in urban slum and non-slum areas of Rawalpindi," Habitat Int., vol. 73, pp. 16-24, 2018.

[8] M. Nisbett, "Empowering the empowered? Slum tourism and the depoliticization of poverty," Geoforum, vol. 85, pp. 37-45, 2017.

[9] A. Y. Katukiza, M. Ronteltap, C. B. Niwagaba, J. W. A. Foppen, F. Kansiime, and P. N. L. Lens, "Sustainable sanitation technology options for urban slums," Biotechnol. Adv., vol. 30, no. 5, pp. 964-978, 2012.

[10] K. Annapuranam, "Exploring perceived health differences among married women in an urban slum of Tamil Nadu, India," City, Cult. Soc., p. 100338, 2020.

[11] R. de Bercegol and J. Monstadt, "The Kenya Slum Electrification Program. Local politics of electricity networks in Kibera," Energy Res. Soc. Sci., vol. 41, pp. 249-258, 2018.

[12] S. Smit, J. K. Musango, Z. Kovacic, and A. C. Brent, "Conceptualising slum in an urban African context," Cities, vol. 62, pp. 107-119, 2017. 
International Journal of Engineering Research and Technology. ISSN 0974-3154, Volume 13, Number 9 (2020), pp. 2374-2379

(C) International Research Publication House. https://dx.doi.org/10.37624/IJERT/13.9.2020.2374-2379

[13] D. Spuhler et al., "Developing sanitation planning options: A tool for systematic consideration of novel technologies and systems," J. Environ. Manage., vol. 271, p. 111004, 2020.

[14] J. Kithiia and G. Majambo, "Motion but no speed: Colonial to post-colonial status of water and sanitation service provision in Mombasa city," Cities, vol. 107, p. 102867, 2020.

[15] Mukhlasin, M. Fitri, and A. Elengoe, "Sanitation of RoRo vessel at the port of ferry branch Merak Banten Indonesia," Enfermería Clínica, vol. 30, pp. 213-215, 2020 . 